\title{
Factors associated with contraceptive use in rural Nepal: gender and decision- making
}

\author{
*Preeti K Mahato ${ }^{1}$, Zoe A. Sheppard ${ }^{2}$, Edwin van Teijlingen ${ }^{3}$, Nisa De Souza ${ }^{4}$
}

1. Centre for Midwifery, Maternal \& Perinatal Health, Faculty of Health \& Social Sciences, Bournemouth House, 19 Christchurch Road, Bournemouth University, Bournemouth BH1 3LH, England, UK, Email: pmahato@bournemouth.ac.uk

2. Dorset County Hospital, Dorchester, UK, Email: Zoe.Sheppard@ dchft.nhs.uk

3. Bournemouth University, Bournemouth, UK \& Manmohan Memorial Institute of Health Sciences, Tribhuvan University, Nepal, evteijlingen@bournemouth.ac.uk

4. Singapore Clinical Research Institute, Duke-NUS Graduate Medical School, Singapore, Email: nisa_desouza@yahoo.com

\section{Highlights}

- A secondary analysis was conducted from primary data collected in 2012 as a quantitative cross-sectional study in four villages of a hilly district in Nepal.

- Gender was associated with current/ever use of contraceptives but decision-making was not found associated with current/eve use of contraceptives.

- Socio-economic factors such as husband's and wife's education; and indicators showing sharing of childcare responsibilities were found to be associated with contraceptive use.

- Educational, health promotional and family planning programmes involving husbands are needed to promote use of contraceptives. 


\begin{abstract}
Introduction: Gender norms and roles influence many decisions related to reproductive health behaviours including contraceptive use. There are very few studies related to gender norms and decision-making in contraceptive use in Nepal, hence this paper addresses these issues in a quantitative study.
\end{abstract}

Methods: A secondary data analysis of a primary study conducted in 2012 as a quantitative cross-sectional study in four villages of a hilly district in Nepal. This study included data that were collected from either the woman or the man in 440 couples of childbearing age with at least one child. The secondary analysis included (adjusted) regression analysis to investigate factors associated with contraception use with the variables of interest being gender roles and decisionmaking, whilst considering demographic and socio-economic controls.

Results: The secondary data analysis found gender roles were associated with current/ever use of contraceptives as reported by the respondents. Socio-economic factors such as husband's and wife's education and gender roles such as indicators showing sharing of childcare responsibilities affected contraceptive use positively. However, decision making regarding contraceptive use was not found to be associated with current/ever use of contraceptives.

Conclusion: Gender has a role in the use of contraceptive, however decision-making may not be associated with contraceptive use. Educational, health promotional and family planning programmes are recommended to promote use of contraceptives. It is important that husbands get involved in these programmes to encourage discussions related to contraceptive use. 


\section{Introduction}

Contraceptive use is one of the most effective methods for reducing the number of pregnancies and thus benefiting the health and survival of women and children (1). Increased contraceptive use decreases fertility which in turn results in lower obstetric risk mainly by reducing unwanted pregnancy in women with high parity (1). Contraceptive use has the potential to avert $32 \%$ of all maternal deaths and nearly $10 \%$ of all childhood deaths (2). There are two main types of contraceptive methods: modern and non-modern. Hubacher and Trussell (3) define a modern contraceptive method as "a product or medical procedure that interferes with reproduction from acts of sexual intercourse" (p. 420). The methods that do not fall under this definition can alternatively be labelled as non-modern methods (3). In 2015, 64\% of women of reproductive age worldwide used some form of contraception, however usage was much lower in low-income countries (40\%). In the same year, $57 \%$ of women of reproductive age used a modern method of family planning which constituted $90 \%$ of contraceptive users (4). In 2017 the modern contraceptive prevalence rate among women of reproductive age was $46 \%$, while unmet need for modern methods was $22 \%$ with less than $1 \%$ of growth in modern contraceptive use in Asia since 2012 (5). The demand satisfied with modern methods was 68\% in 2017 (5).

Studies in low-income countries have shown that gender norms influence contraceptive decisionmaking among men and women $(6,7)$. In such contexts, men are often the primary decisionmakers for reproductive health and behaviours including contraceptive use (6, 8-10). Gender roles are strong and are reflected in almost every social institution including family structures, household responsibilities, labour markets, health systems, schools, laws and policies (11). However, some studies have also shown that women often play the role of contraceptive gatekeeper, that is, they initiated the discussion and took decisions about contraceptive use (12). Studies have suggested that increasing women's autonomy and self-esteem is associated with higher contraception use $(13,14)$.

In Nepal, the contraceptive prevalence rate was 53\% in 2016 according to a national survey (15), with $43 \%$ using modern methods. However, there has been no change in modern methods of contraception since 2006 which is a matter of concern. The Sustainable Development Goal (SDG) number 5 - gender equality, has a specific target related to sexual and reproductive health and rights that states "to ensure universal access to sexual and reproductive health and reproductive rights" (16). Access to sexual and reproductive health also includes access to and use of contraceptives. Being a member of the United Nations, Nepal has adopted the SDGs. However, the current situation shows inequity in decision-making among men and women as well as gender norms in decision-making and both impact on contraceptive use in Nepal (17). The use of modern contraceptive methods was higher among women who participated in one or more decisions and negotiated for safer sexual relations (17). Studies in Nepal have indicated several factors affecting contraceptive use including spousal communication (18), household characteristics, a community's socioeconomic development, access to modern contraceptives, 
community level gender norms regarding decision-making for family planning and community norms regarding marriage and childbirth (19). However, there is limited literature about the role of gender norms and contraceptive decision-making in Nepal. Therefore, this paper explores the factors involved in contraceptive use in rural areas of a district in Nepal and specifically focuses on the role of gender norms and decision-making.

\section{Material and Methods}

This study involved a secondary analysis of primary data collected in 2012-2013. The first author was involved in the primary research and a publication reporting the basic descriptive analysis (20). This study reports on further in-depth analyses of these primary data.

The primary research was a cross-sectional study conducted in four village development committees (VDCs) of Syangja district, located in the western hilly region of Nepal. A VDC used to be the smallest local administrative unit in rural Nepal consisting of a few villages, which was replaced by rural municipalities in 2017 (after this research) (21). Proportionate sampling was used to identify the sample from each VDC and systematic random sampling was used to identify the final participants. Respondents $(n=440)$ included either partner within the family unit (male or female) of reproductive age (15-49 years) who had at least one child of one year of age. A structured questionnaire collected various elements including socio-demographic and economic characteristics; decision making characteristics regarding pregnancy, contraceptive use and birth-spacing; and gender norms related to parenting and childcare. Students were assigned as data collectors after providing training and instruction about the study objectives and methods. However, there was constant monitoring and supervision of data collectors to ensure validity and reliability. The collected data were entered into the Statistical Package for the Social Sciences (SPSS) (IBM SPSS Inc., USA).

The initial study was approved by the Research Committee of the School of Health and Allied Sciences, Pokhara University, Nepal. No ethical approval was sought for the secondary analysis. The authors only had access to anonymous data.

\section{Secondary statistical analysis}

SPSS was used to investigate factors associated with current and ever use of contraception with the variables of interest being gender roles and decision-making, whilst considering demographic and socio-economic controls. Age was categorised into five-year age groups for consistency with similar large-scale surveys e.g. the Demographic and Health Survey (17). Since few women were married after 25 years, age at marriage was dichotomised into teenage years ( $\leq 19$ years) and above (20+ years), and consistently so for men. The age difference between spouses was collapsed using five years as the cut-off, given this was the approximate value of both the mean and median. Similarly, only 11 participants had been married for $25+$ years so duration of marriage was collapsed into a binary variable using ten years as the cut-off, given both the mean 
and median was approximately 9 years. With regards to socio-economic status, the husband and wife's education was recoded into similar categories - below secondary education, secondary education, and above secondary education. Their occupation was classified into similar groupings i.e. service/business versus other. With regards to the variables measuring gender roles, the possibility of 'role reversal' was re-coded into ordered groups (possible through to impossible). Since only few $(n=12)$ thought that the husband was the best carer, this group was combined with those who thought that both husband and wife were the best carer.

The analysis was based on the variables with complete/imputed data $(n=440)$. Descriptive findings were presented - percentages for categorical variables, and the median with interquartile range for the non-normally distributed data. As the outcome variables of current and ever contraceptive use were dichotomous (no/yes), logistic regression (22) was used to investigate the factors associated with these variables. First each of the variables was entered separately into a regression to produce the unadjusted odds ratios. Then the most meaningful variables were adjusted for - as there were 26 variables, only those with a significance level of $\mathrm{p}<0.001$ were included in the adjusted model. Given there was potential for collinearity with several of the variables, the variable that explained most of the variance in the data (determined by the Nagelkerke R square) was chosen when this was considered to be the case (22).

\section{Findings}

Forty percent of participants (Table 1) reported currently using contraception compared to twothirds having ever used contraception (the outcome variables). With regards to the demographic characteristics, nearly two-thirds of the sample was female and half were aged 25-34 years. Whilst most wives had been married in their teens (63\%), the minority of husbands were (8\%), highlighting the potential age difference between spouses. Indeed, just over half of respondents had an age difference of at least five years with their spouse. There was a reasonably equal split in the proportion married less than a decade compared to at least ten years. Nearly two-thirds were in a nuclear household and the median desirable family size was the same as the actual family size $(n=4)$. Similarly, the median number of living male children was the same as female $(n=1)$ whereas the median number of pregnancies and number of living children was two. With regards to socio-economic characteristics, the majority of both husbands and wives had at least secondary education ( $87.5 \%$ and $80.5 \%$ respectively). However, in contrast, nearly threequarters of husbands were employed in the service/business industry compared to under a third of wives.

Moving to the gender and decision-making characteristics, of particular interest to this study, $70 \%$ thought that childcare was not the sole responsibility of the female. Indeed, nearly $40 \%$ thought that the husband provided adequate time for childcare responsibilities. However, nearly a third thought that it was 'impossible' for the husband to assume the childcare responsibilities with the wife going out to work ('role reversal'). Related to this, $70 \%$ thought that the wife only 
was the best carer. Despite this, over $70 \%$ reported discussion between the couple about maintaining family size and $41 \%$ reported that both spouses would discuss and decide if they were in opposition with each other. Similarly, three-quarters mutually decided about pregnancy compared to $64 \%$ on the first pregnancy but over $80 \%$ about birth spacing.

[Table 1 about here]

Table 2 presents the unadjusted and adjusted findings from the logistic regression of current contraceptive use. Only eight of the 26 variables were not significantly ( $p \geq 0.05)$ associated with current contraceptive use - husband and wife's age at marriage; number of female children; husband's employment; possibility of role reversal; discussion between couple to maintain family size and when in opposition with each other, and about birth spacing. As there would not be the power to include the remaining variables in the same model, only those that were highly significantly associated with current contraceptive use $(\mathrm{p}<0.001)$ were included and where there were thought to be issues of potential collinearity, the variable that explained the most variance in the data was included - desirable family size over family size, times pregnant, and the number of male/female/total children.

The adjusted model indicates that men were three times (Odds Ratio (OR): 3.107, 95\% Confidence Interval (CI): 1.759-5.490) as likely to report current contraceptive use compared to women. Respondents aged 30-34 years were nearly two-and-a-half times more likely to report current use than those aged 20-24 years (OR: 2.406, 95\% CI: 1.066-5.428). However, those in joint families were less likely to report current family planning compared to those in nuclear households (OR: 0.448; 95\% CI: 0.245-0.817). Desirable family size and husband's educational level became non-significant after adjusting for these other factors ( $p \geq 0.05)$. In contrast, the wife's education level remained significant and surprisingly those with secondary education were less likely to report current use compared to those with below secondary education (OR: 0.240, 95\% CI: 0.107-0.539). Respondents reporting husbands with the 'least time' for childcare were over two-and-a-half times as likely to report family planning use at the time of the survey than those reporting adequate time (OR: 2.650, 95\% CI: 1.225-5.735). Finally, those reporting that both the husband and wife were the best carer were twice as likely to report current contraceptive use compared to the wife (OR: 2.076, 95\% CI: 1.238-3.479).

[Table 2 about here]

The unadjusted and adjusted results from the logistic regression of having ever used contraception are presented in Table 3. Again, most variables were significantly associated with ever use of contraception $(\mathrm{p}<0.05)$. Only six of the 26 variables were found non-significant similarly husband's age at marriage and occupation but interestingly the majority (four out of five) of the decision-making variables were non-significant with this outcome. Again, as there 
was not the power to include the remaining variables in the adjusted model, those found highly significantly associated with ever contraceptive use $(\mathrm{p}<0.001)$ were included, and those with the highest Nagelkerke's R square where there were potential issues of collinearity - this time this included the total number of living children over desirable family size, actual family size, and the number of times pregnant/males/females.

In the adjusted model, male respondents were twice as likely to report ever use of contraception compared to female (OR: 2.188, 95\% CI: 1.121-4.272). However, age, duration of marriage, and family type were no longer significant $(\mathrm{p} \geq 0.05)$ when adjusting for these other variables. With each additional child, the odds of ever contraceptive use increased by $107 \%$ (OR: 2.065 , 95\% CI: 1.373-3.106). With regards to socio-economic status, husbands with secondary education were less likely to report ever use of contraception than those with below secondary education (OR: 0.135, 95\% CI: 0.042-0.436). Moving to the gender roles of particular interest to this study and more intuitive was that those who thought that women should not have the sole childcare responsibilities were nearly three times as likely to report ever contraceptive use compared to those who thought they should (OR: 2.760, 95\% CI: 1.494-5.101). However, there were mixed findings with regards to time provided by the husband for childcare.

[Table 3 about here]

\section{Discussion}

Many factors were found to be associated with both current and ever use of contraception and indeed there was some similarity in the variables associated with each of these outcomes. Gender roles seemed to be of importance to both current and ever use of contraception, more so than decision-making.

\section{Gender roles}

This study found that a greater part was played by gender roles in determining use of contraceptives among the couples. Our finding agrees with existing literature that gender may play a role in the use of contraceptives $(10,23,24)$. However, the results also contradicted other research which reported no role of gender in use of contraceptives (25). The results of this study imply that the government should involve men along with women while conducting family planning programmes and health promotion interventions. Nanda et al. (24) report that more equitable gender attitudes mean more use of contraception by women, therefore the programmes aimed at family planning should involve both men and women. Although this study did not measure gender attitudes separately for men and women as by Nanda et al. (24), the majority of the participants in our study were women $(64.8 \%)$. In this study gender roles were found to be significant in the findings of both current and ever use of contraception. Similarly, programmes that integrated a gender perspective into interventions to prevent unintentional pregnancies were 
found to be successful in Nepal $(26,27)$. This suggests involvement of both genders in family planning programmes would be helpful in increasing contraceptive use.

\section{Decision-making}

There is less evidence that the decision-making process is associated with contraceptive use. This is contrary to other studies which have shown that contraceptive use is affected by decisionmaking with regards to contraceptive use by men (14). Our finding is not easy to explain as Gurung and Acharya (28) reported very high levels of violence against women in Syangja District, which they blamed on patriarchy. However, one study in the United States reported that decision-making regarding contraceptive use is not made by men but by women themselves who act as contraceptive gatekeepers (12). Another study also reported $29 \%$ more contraceptive use in the community where women commonly had unilateral control over household decisions (29). This suggests that women should be supported in their decision-making related to household matters and also contraceptive use.

\section{Socio-economic factors}

Socio-economic factors were associated with current and ever use of contraception - both husband and wife's education for current use, and husband's education for ever use. Similar to this study, a study in India (25) and another in Iran (30) reported the role of socio-cultural factors especially husband's and wife's education level in determining the use of contraceptives. However, it is a matter of concern that in this study wives with secondary education were less likely to report current use than those with below secondary education - the same for husbands with ever use. This requires further exploration as studies in Guatemala (31) and Angola (32) reported increased use of contraceptives with increase in education level, contrary to the findings of this study.

Those aged 30-34 years were found to be more likely to report current use of contraceptives than those aged 20-24 years. This was similar to a study in USA (33) where older women aged 25-34 years were more likely to report current use of contraceptives than younger women. However, the findings of this study were opposite to what the study in Iran (30) reported where younger women were more likely to use modern contraceptives than older women and in Bangladesh where contraceptive use decreased with age (34). The findings of this study suggest that in order to prevent unintended pregnancy, younger people aged less than 25 years need to be targeted. Policy makers need to provide educational programmes for this age group focusing on the importance of contraceptive use and dangers of unintended pregnancy.

\section{Child rearing}

Where men were seen as sharing the responsibility of rearing a child (e.g. 'both the husband and wife were the best carer'), the respondents were more likely to report current use of contraceptives. This could be related to women being given more autonomy and men sharing the 
responsibility of rearing a child along with women. This can be explained by the fact that the district of 'Syangja' where the research was carried out has half the poverty rate of Nepal overall (11.8\% in Syangja, 23.48\% in Nepal) (35) and the people of Syangja who have completed secondary level of education is about 1.3 times higher than the rate in Nepal (15.2\% in Syangja, $11.54 \%$ in Nepal) (36). The odds of ever use of contraceptives increased with each additional living child as in a study in South Africa where use of contraception increased with one or more children than no child (14).

\section{Strengths and limitations}

There are several strengths and limitations of this study. The primary analysis only showed that mutual decision-making on reproductive behaviour existed, but it was based only on descriptive findings. However, this study found little association between contraceptive use and decisionmaking once other factors were controlled for in logistic regression analysis. Also, the primary study did not focus on gender norms and use of contraceptives but mostly on decision-making. On the contrary this secondary analysis found an association between gender and use of contraceptives. Although the primary analysis found that gender norms were changing based on the decision-making characteristics (20), the results of this secondary analysis indicate that decision-making may work through gender roles in determining contraceptive use. The main limitation of the study is that only associations could be determined rather than causal relationships. However, this study emphasises the need for gender and age-specific education interventions about the benefits and utility of contraception.

\section{Conclusion}

This study's findings convey that gender plays a role in the use of contraceptives. However, there is less evidence that the decision-making process is associated with the use of contraceptives. Indeed, it could be that decision-making is working through gender which requires further exploration. Since gender roles affect contraceptive use, there is a need for the government to introduce educational programmes that can help increase uptake of contraceptives. Similarly, health promotion interventions and family planning programmes involving husbands along with their wives need to be introduced so that they are encouraged to get involved in discussions related to contraceptive use.

\section{Acknowledgements}

The authors thank Mr Sudarshan Subedi who agreed to the use of the primary data for this secondary analysis and for providing all the details related to the primary data.

\section{Conflict of interest}

The authors declare no conflict of interest. 


\section{References}

1. Cleland J, Conde-Agudelo A, Peterson H, Ross J, Tsui A. Contraception and health. The Lancet. 2012; 379(9837):149-56.

2. Cleland J, Bernstein S, Ezeh A, Faundes A, Glasier A, Innis J. Family planning: the unfinished agenda. The Lancet. 2006; 368(9549):1810-1827.

3. Hubacher D, Trussell J. A definition of modern contraceptive methods. Contraception. 2015; 92:420-421.

4. United Nations. Trends in Contraceptive Use Worldwide 2015. Department of Economic and Social Affairs, Population Division; New York; 2015. Available from: http://www.un.org/en/development/desa/population/publications/pdf/family/trendsContracept iveUse2015Report.pdf. Accessed 5 June 2019.

5. Cahill N, Sonneveldt E, Stover J, Weinberger M, Williamson J, Wei C, Brown W, Alkema L. Modern contraceptive use, unmet need, and demand satisfied among women of reproductive age who are married or in a union in the focus countries of the Family Planning 2020 initiative: a systematic analysis using the Family Planning Estimation Tool. The Lancet. 2018; 391(10123): 870-882.

6. Mason KO, Smith HL. Husbands' versus wives' fertility goals and use of contraception: the influence of gender context in five Asian countries. Demography. 2000; 37(3):299-311.

7. Adams MK, Salazar E, Lundgren R. Family planning: Tell them you are planning for the future: Gender norms and family planning among adolescents in northern Uganda. International Journal of Gynecology \& Obstetrics. 2013; 123(Supplement 1):e7-e10.

8. Green CP, Chohen SI, Belhadj-El Ghouayel H. Male involvement in reproductive health, including family planning and sexual health. Technical report 28. New York, N.Y. : United Nations Population Fund; 1995, p 104. Available from:

https://www.popline.org/node/295292. Accessed on 10 February 2020.

9. Grady WR, Tanfer K, Billy JO, Lincoln-Hanson J. Men's perceptions of their roles and responsibilities regarding sex, contraception and childrearing. Family Planning Perspectives. 1996; 28(5):221-6.

10. Mishra A, Nanda P, Speizer IS, Calhoun LM, Zimmerman A, Bhardwaj R. Men's attitudes on gender equality and their contraceptive use in Uttar Pradesh India. Reproductive Health. 2014; 11(1):41.

11. Branisa B, Klasen S, Ziegler M. Gender Inequality in Social Institutions and Gendered Development Outcomes. World Development. 2013; 45:252-268.

12. Fennell JL. Men bring condoms, women take pills: Men's and women's roles in contraceptive decision making. Gender \& Society. 2011; 25(4):496-521.

13. Rahman MM, Mostofa MG, Hoque MA. Women's household decision-making autonomy and contraceptive behavior among Bangladeshi women. Sexual \& Reproductive Healthcare. 2014; 5:9-15.

14. Peer N, Morojele N, London L. Factors associated with contraceptive use in a rural area in Western Cape Province. South African Medical Journal. 2013;103(6):406-12. 
15. Ministry of Health, New ERA, ICF. Nepal Demographic and Health Survey 2016. Kathmandu, Nepal: Ministry of Health, Nepal.; 2017. Available from:

16. United Nations. Sustainable Development Goals: 17 goals to transform our world. Available from: https://www.un.org/sustainabledevelopment/gender-equality/Accessed 7 April 2019.

17. Ministry of Health and Population, New Era, Inc II. Nepal Demographic and Health Survey 2011. 2012. Available from: https://dhsprogram.com/pubs/pdf/fr257/fr257\%5B13april2012\%5D.pdf. Accessed 8 April 2019.

18. Link CF. Spousal Communication and Contraceptive Use in Rural Nepal: An Event History Analysis. Studies in Family Planning. 2011:42(2):83-92.

19. Wang WJ, Alva S, Winter R, Burgert C. Contextual influences of modern contraceptive use among rural women in Rwanda and Nepal. DHS Analytical Studies. Calverton; USA: ICF Macro; 2013. Available from: http://paa2014.princeton.edu/papers/141380. Accessed on 19 February 2020.

20. Subedi S, Mahato P, Acharya S, Kafle HP. Gender roles and practice of decision making on reproductive behavior among couples of Syangja district, Nepal. International Journal of Reproduction, Contraception, Obstetrics and Gynecology. 2013 (3):414.

21. The Asia Foundation. Diagnostic Study of Local Governance in federal Nepal 2017. Kathmandu: The Asia Foundation. Available at: https://asiafoundation.org/wp-content/uploads/2018/07/Diagnostic-Study-of-LocalGovernance-in-Federal-Nepal-07112018.pdf. Accessed on 15 January 2020.

22. Field A. Discovering statistics using IBM SPSS statistics: and sex and drugs and rock ' $n$ ' roll. $4^{\text {th }}$ edition, SAGE, Los Angeles, 2013.

23. Ngum Chi Watts MC, McMichael C, Liamputtong P. Factors influencing contraception awareness and use: the experiences of young African Australian mothers. Journal of Refugee Studies. 2015; 28(3):368-87.

24. Nanda G, Schuler SR, Lenzi R. The influence of gender attitudes on contraceptive use in Tanzania: New evidence using husband's and wives' survey data. Journal of Biosocial Science. 2013; 45(3): 331-344.

25. Jeyalakshmi K, Ranjani P, Sonia K, Kumari HS. Socio-Cultural and Norms Factors Influencing Contraception use among Adult Female in Urban Areas of Dakshina Kannada District. International Journal of Nursing Education. 2012;4(2):107-110.

26. Centre for Research on Environmental Health and Population Activities (CREHPA) (2002) Enabling Women for Reproductive Health: The REWARD Project. CEDPA, Washington, DC, USA

27. Centre for Development and Population Activities (CEDPA) (2005) New Vision: Life Skills Education for Boys. CEDPA, Washington, DC, USA

28. Gurung S, Acharya J. Gender-based violence among pregnant women of Syangja district, Nepal. Osong Public Health and Research Perspectives. 2016; 7(2):101-107. 
29. DeRose LF, Ezeh AC. Decision-making patterns and contraceptive use: evidence from Uganda. Population Research and Policy Review. 2010; 29: 412-439.

30. Sadat-Hashemi SM, Ghorbani R, Majdabadi HA, Farahani FK. Factors associated with contraceptive use in Tehran, Iran. The European Journal of Contraception \& Reproductive Health Care2007;12(2):148-53.

31. Glei DA, Goldman N, Rodriguez G. Utilization of care during pregnancy in rural Guatemala: does obstetrical need matter? Social Science \& Medicine. 2003; 57(12):244763.

32. Decker M, Constantine NA. Factors associated with contraceptive use in Angola. African Journal of Reproductive Health. 2011;15(4):68-77.

33. Glei DA. Measuring contraceptive use patterns among teenage and adult women. Family Planning Perspectives. 1999:73-80.

34. Haq I, Sakib A, Talukder A. Sociodemographic factors on contraceptive use among evermarried women of reproductive age: edidence from three demographic and health surveys in Bangladesh. Medical Science (Basil). 2017;5 (4): pii: E31.

35. OpenNepal. Poverty rates on district level, 2001-2011. 2013 . Available from: http://data.opennepal.net/content/poverty-rates-district-level-2001-2011. Accessed date 20 April 2019.

36. Central Bureau of Statistics. Statistical year book of Nepal 2013. 2014. Available from: http://cbs.gov.np/atlas/index.html. Accessed date 21 April 2019. 
Table 1: Contraceptive use, demographic characteristics, socio-economic characteristics, gender characteristics, and decision-making characteristics $(n=440)$

\begin{tabular}{|c|c|c|c|}
\hline Variable & Categories & Frequency & Percentage \\
\hline \multicolumn{4}{|l|}{ Outcome variables } \\
\hline \multirow[t]{2}{*}{ Currently using contraception } & Yes & 177 & 40.2 \\
\hline & No & 263 & 59.8 \\
\hline \multirow[t]{2}{*}{ Ever use of contraception } & Yes & 288 & 65.5 \\
\hline & No & 152 & 34.5 \\
\hline \multicolumn{4}{|l|}{ Demographic characteristics } \\
\hline \multirow[t]{2}{*}{ Sex } & Female & 285 & 64.8 \\
\hline & Male & 155 & 35.2 \\
\hline \multirow[t]{5}{*}{ Age group } & 20-24 years & 84 & 19.1 \\
\hline & $25-29$ years & 111 & 25.2 \\
\hline & $30-34$ years & 111 & 25.2 \\
\hline & $35-39$ years & 71 & 16.1 \\
\hline & $40+$ years & 63 & 14.3 \\
\hline \multirow[t]{2}{*}{ Husband's age at marriage } & Teenage years & 35 & 8.0 \\
\hline & $20+$ years & 405 & 92.0 \\
\hline \multirow[t]{2}{*}{ Wife's age at marriage } & Teenage years & 277 & 63.0 \\
\hline & $20+$ years & 163 & 37.0 \\
\hline \multirow[t]{2}{*}{ Age difference between spouses } & $<5$ years & 214 & 48.6 \\
\hline & $5+$ years & 226 & 51.4 \\
\hline \multirow[t]{2}{*}{ Duration of marriage } & $<10$ years & 227 & 51.6 \\
\hline & $10+$ years & 213 & 48.4 \\
\hline \multirow[t]{2}{*}{ Family type } & Nuclear & 288 & 65.5 \\
\hline & Joint & 152 & 34.5 \\
\hline Desirable family size & Median (inter-quartile range) ${ }^{\mathrm{a}}$ & 4.0 & $4.0-4.0$ \\
\hline Family size & Median (inter-quartile range) ${ }^{\mathrm{a}}$ & 4.0 & $3.0-5.0$ \\
\hline Times of pregnancy & Median (inter-quartile range) & 2.0 & $1.0-3.0$ \\
\hline Number of living male children & Median (inter-quartile range) ${ }^{\mathrm{a}}$ & 1.0 & $0.0-1.0$ \\
\hline Number of living female children & Median (inter-quartile range) & 1.0 & $0.0-1.0$ \\
\hline Total number of living children & Median (inter-quartile range) ${ }^{\mathrm{a}}$ & 2.0 & $1.0-3.0$ \\
\hline \multicolumn{4}{|l|}{ Socio-economic characteristics } \\
\hline \multirow{3}{*}{ Husband's educational level } & Below secondary & 55 & 12.5 \\
\hline & Secondary & 227 & 51.6 \\
\hline & Above secondary & 158 & 35.9 \\
\hline \multirow[t]{3}{*}{ Wife's educational level } & Below secondary & 86 & 19.5 \\
\hline & Secondary & 219 & 49.8 \\
\hline & Above secondary & 135 & 30.7 \\
\hline \multirow[t]{2}{*}{ Husband's employment } & Unemployed/farming/other & 118 & 26.8 \\
\hline & Service/business & 322 & 73.2 \\
\hline \multirow[t]{2}{*}{ Wife's employment } & Housewife/farming/other & 304 & 69.1 \\
\hline & Service/business & 136 & 30.9 \\
\hline Gender characteristics & & & \\
\hline
\end{tabular}




\begin{tabular}{llrr}
\hline $\begin{array}{l}\text { View on sole responsibility of } \\
\text { female spouse in nurturing and } \\
\text { caring of children }\end{array}$ & Yes & 131 & 29.8 \\
& & & \\
Time provided by husband for & No & 309 & 70.2 \\
nurturing and caring of the baby & Adequate time & 166 & 37.7 \\
& Some time & 128 & 29.1 \\
& Least time & 59 & 13.4 \\
& Not at all & 87 & 19.8 \\
Possibility of role reversal & Possible & 84 & 19.1 \\
& Somewhat possible & 154 & 35.0 \\
& May be possible & 60 & 13.6 \\
Best carer & Impossible & 142 & 32.3 \\
& Wife & 308 & 70.0 \\
Decision-making characteristics & Husband/both & 132 & 30.0 \\
Discussion between couple to & Yes & & \\
maintain family size & & 318 & 72.3 \\
& No & 122 & 27.7 \\
Discussion on family size if spouses & Respondent's decision & 119 & 27.0 \\
in opposition with each other & & & \\
& Spouse's decision & 60 & 13.6 \\
& Both discuss and decide & 178 & 40.5 \\
Decision maker of pregnancy & Not happened yet & 83 & 18.9 \\
& Husband & 67 & 15.2 \\
Decision maker of first pregnancy & Wife & 44 & 10.0 \\
& Mutual decision & 329 & 74.8 \\
& Husband & 48 & 10.9 \\
& Wife & 28 & 6.4 \\
Decision maker of birth spacing & Mutual decision & 282 & 64.1 \\
& Casual & 82 & 18.6 \\
& Husband & 44 & 10.0 \\
& Wife & 32 & 7.3 \\
& Both & 364 & 82.7 \\
\hline Median and & &
\end{tabular}

${ }^{\mathrm{a}}$ Median and inter-quartile range presented as data non-normally distributed 
Table 2: Logistic regression of current use of contraception $(n=440)$

\begin{tabular}{|c|c|c|c|c|c|c|c|}
\hline \multirow{2}{*}{ Variable } & \multirow[b]{2}{*}{ Categories } & \multicolumn{3}{|c|}{ Unadjusted } & \multicolumn{3}{|c|}{ Adjusted } \\
\hline & & $\begin{array}{l}\text { Odds } \\
\text { ratio }\end{array}$ & $\begin{array}{c}\text { p- } \\
\text { value }\end{array}$ & $\begin{array}{c}\mathbf{R} \\
\text { square }^{\mathbf{a}}\end{array}$ & $\begin{array}{l}\text { Odds } \\
\text { ratio }\end{array}$ & $\begin{array}{c}95 \% \\
\mathbf{C I}^{\mathrm{b}}\end{array}$ & $\begin{array}{c}\text { p- } \\
\text { value }\end{array}$ \\
\hline \multicolumn{8}{|l|}{ Demographics } \\
\hline \multirow[t]{2}{*}{ Sex } & Female $\left(\mathrm{RC}^{\mathrm{c}}\right)$ & 1.000 & & 0.196 & 1.000 & & \\
\hline & Male & 5.648 & $<0.001$ & & 3.107 & $\begin{array}{l}1.759- \\
5.490\end{array}$ & $<0.001$ \\
\hline \multirow[t]{5}{*}{ Age group } & $\begin{array}{l}\text { 20-24 years } \\
(\mathrm{RC})\end{array}$ & 1.000 & $<0.001$ & 0.121 & 1.000 & & 0.005 \\
\hline & $25-29$ years & 2.040 & 0.038 & & 1.168 & $\begin{array}{l}0.512- \\
2.664\end{array}$ & 0.712 \\
\hline & $30-34$ years & 3.612 & $<0.001$ & & 2.406 & $\begin{array}{l}1.066- \\
5.428\end{array}$ & 0.034 \\
\hline & 35-39 years & 8.323 & $<0.001$ & & 2.345 & $\begin{array}{c}0.863- \\
6.371\end{array}$ & 0.095 \\
\hline & $40+$ years & 3.187 & 0.002 & & 0.624 & $\begin{array}{l}0.221- \\
1.763\end{array}$ & 0.373 \\
\hline \multirow[t]{2}{*}{$\begin{array}{l}\text { Husband's age } \\
\text { at marriage }\end{array}$} & $\begin{array}{l}\text { Teenage years } \\
\text { (RC) }\end{array}$ & 1.000 & & 0.009 & & & \\
\hline & $20+$ years & 0.539 & 0.081 & & & & \\
\hline \multirow[t]{2}{*}{$\begin{array}{l}\text { Wife's age at } \\
\text { marriage }\end{array}$} & $\begin{array}{l}\text { Teenage years } \\
\text { (RC) }\end{array}$ & 1.000 & & 0.005 & & & \\
\hline & $20+$ years & 1.296 & 0.196 & & & & \\
\hline \multirow{2}{*}{$\begin{array}{l}\text { Age difference } \\
\text { between } \\
\text { spouses }\end{array}$} & $<5$ years $(\mathrm{RC})$ & 1.000 & & 0.016 & & & \\
\hline & $5+$ years & 0.636 & 0.021 & & & & \\
\hline \multirow{2}{*}{$\begin{array}{l}\text { Duration of } \\
\text { marriage }\end{array}$} & $<10$ years $(\mathrm{RC})$ & 1.000 & & 0.027 & & & \\
\hline & $10+$ years & 1.792 & 0.003 & & & & \\
\hline \multirow[t]{2}{*}{ Family type } & Nuclear (RC) & 1.000 & & 0.058 & 1.000 & & \\
\hline & Joint & 0.394 & $<0.001$ & & 0.448 & $\begin{array}{l}0.245- \\
0.817\end{array}$ & 0.009 \\
\hline $\begin{array}{l}\text { Desirable } \\
\text { family size }\end{array}$ & & 1.789 & $<0.001$ & 0.055 & 1.423 & $\begin{array}{l}0.984- \\
2.058\end{array}$ & 0.061 \\
\hline Family size & & 1.414 & $<0.001$ & 0.041 & & & \\
\hline $\begin{array}{l}\text { Times of } \\
\text { pregnancy }\end{array}$ & & 1.370 & $<0.001$ & 0.039 & & & \\
\hline $\begin{array}{l}\text { Number of } \\
\text { living male } \\
\text { children }\end{array}$ & & 1.589 & $<0.001$ & 0.042 & & & \\
\hline $\begin{array}{l}\text { Number of } \\
\text { living female } \\
\text { children }\end{array}$ & & 1.097 & 0.401 & 0.002 & & & \\
\hline
\end{tabular}




\begin{tabular}{|c|c|c|c|c|c|c|c|}
\hline $\begin{array}{l}\text { Total number } \\
\text { of living } \\
\text { children } \\
\text { Socio- } \\
\text { economics }\end{array}$ & & 1.476 & $<0.001$ & 0.047 & & & \\
\hline \multirow[t]{3}{*}{$\begin{array}{l}\text { Husband's } \\
\text { education }\end{array}$} & $\begin{array}{l}\text { Below } \\
\text { secondary (RC) }\end{array}$ & 1.000 & $<0.001$ & 0.100 & 1.000 & & 0.249 \\
\hline & Secondary & 0.220 & $<0.001$ & & 0.738 & $\begin{array}{c}0.316- \\
1.721\end{array}$ & 0.482 \\
\hline & $\begin{array}{l}\text { Above } \\
\text { secondary }\end{array}$ & 0.571 & 0.083 & & 1.193 & $\begin{array}{c}0.454- \\
3.138\end{array}$ & 0.721 \\
\hline \multirow[t]{3}{*}{$\begin{array}{l}\text { Wife's } \\
\text { education }\end{array}$} & $\begin{array}{l}\text { Below } \\
\text { secondary (RC) }\end{array}$ & 1.000 & $<0.001$ & 0.100 & 1.000 & & $<0.001$ \\
\hline & Secondary & 0.266 & $<0.001$ & & 0.240 & $\begin{array}{c}0.107- \\
0.539\end{array}$ & 0.001 \\
\hline & $\begin{array}{l}\text { Above } \\
\text { secondary }\end{array}$ & 0.731 & 0.260 & & 0.632 & $\begin{array}{c}0.238- \\
1.674\end{array}$ & 0.356 \\
\hline $\begin{array}{l}\text { Husband's } \\
\text { employment }\end{array}$ & $\begin{array}{l}\text { Unemployed/ } \\
\text { farming/other } \\
\text { (RC) }\end{array}$ & 1.000 & & 0.003 & & & \\
\hline \multirow[t]{2}{*}{$\begin{array}{l}\text { Wife's } \\
\text { employment }\end{array}$} & $\begin{array}{l}\text { Service/business } \\
\text { Housewife/ } \\
\text { farming/other } \\
\text { (RC) }\end{array}$ & $\begin{array}{l}1.243 \\
1.000\end{array}$ & 0.327 & 0.024 & & & \\
\hline & Service/business & 1.789 & 0.005 & & & & \\
\hline $\begin{array}{l}\text { Gender } \\
\text { View on sole } \\
\text { responsibility } \\
\text { of woman in } \\
\text { nurturing and } \\
\text { caring of } \\
\text { children }\end{array}$ & Yes (RC) & 1.000 & & 0.026 & & & \\
\hline \multirow{4}{*}{$\begin{array}{l}\text { Time provided } \\
\text { by husband for } \\
\text { nurturing and } \\
\text { caring of the } \\
\text { baby }\end{array}$} & $\begin{array}{l}\text { No } \\
\text { Adequate time } \\
\text { (RC) }\end{array}$ & $\begin{array}{l}1.904 \\
1.000\end{array}$ & $\begin{array}{c}0.004 \\
<\mathbf{0 . 0 0 1}\end{array}$ & 0.067 & 1.000 & & 0.032 \\
\hline & Some time & 1.635 & 0.039 & & 1.165 & $\begin{array}{l}0.651- \\
2.087\end{array}$ & 0.607 \\
\hline & Least time & 1.810 & 0.052 & & 2.650 & $\begin{array}{l}1.225- \\
5.735\end{array}$ & 0.013 \\
\hline & Not at all & 0.457 & 0.010 & & 0.757 & $\begin{array}{c}0.348- \\
1.647\end{array}$ & 0.483 \\
\hline $\begin{array}{l}\text { Possibility of } \\
\text { role reversal }\end{array}$ & Possible (RC) & 1.000 & 0.617 & 0.005 & & & \\
\hline
\end{tabular}




\begin{tabular}{|c|c|c|c|c|c|c|c|}
\hline & $\begin{array}{l}\text { Somewhat } \\
\text { possible }\end{array}$ & 0.828 & 0.494 & & & & \\
\hline & May be possible & 1.167 & 0.650 & & & & \\
\hline & Impossible & 0.818 & 0.474 & & & & \\
\hline \multirow[t]{2}{*}{ Best carer } & Wife (RC) & 1.000 & & 0.070 & 1.000 & & \\
\hline & Husband/both & 2.781 & $<0.001$ & & 2.076 & $\begin{array}{l}1.238- \\
3.479\end{array}$ & 0.006 \\
\hline \multicolumn{8}{|l|}{$\begin{array}{l}\text { Decision- } \\
\text { making }\end{array}$} \\
\hline \multirow{2}{*}{$\begin{array}{l}\text { Discussion } \\
\text { between } \\
\text { couple to } \\
\text { maintain } \\
\text { family size }\end{array}$} & Yes (RC) & 1.000 & & 0.001 & & & \\
\hline & No & 0.864 & 0.504 & & & & \\
\hline \multirow{4}{*}{$\begin{array}{l}\text { Discussion on } \\
\text { family size if } \\
\text { spouses } \\
\text { disagree }\end{array}$} & $\begin{array}{l}\text { Respondent's } \\
\text { decision (RC) }\end{array}$ & 1.000 & 0.333 & 0.011 & & & \\
\hline & $\begin{array}{l}\text { Spouse's } \\
\text { decision }\end{array}$ & 1.167 & 0.628 & & & & \\
\hline & $\begin{array}{l}\text { Both discuss } \\
\text { and decide }\end{array}$ & 0.885 & 0.610 & & & & \\
\hline & $\begin{array}{l}\text { Not happened } \\
\text { yet }\end{array}$ & 0.643 & 0.139 & & & & \\
\hline \multirow{3}{*}{$\begin{array}{l}\text { Decision } \\
\text { maker } \\
\text { pregnancy }\end{array}$} & Husband (RC) & 1.000 & 0.001 & 0.072 & & & \\
\hline & Wife & 0.148 & 0.001 & & & & \\
\hline & Mutual decision & 1.182 & 0.540 & & & & \\
\hline \multirow{4}{*}{$\begin{array}{l}\text { Decision } \\
\text { maker first } \\
\text { pregnancy }\end{array}$} & Husband (RC) & 1.00 & 0.005 & 0.047 & & & \\
\hline & Wife & 0.119 & 0.001 & & & & \\
\hline & Mutual decision & 0.464 & 0.015 & & & & \\
\hline & Casual & 0.506 & 0.065 & & & & \\
\hline \multirow{3}{*}{$\begin{array}{l}\text { Decision } \\
\text { maker birth } \\
\text { spacing }\end{array}$} & Husband (RC) & 1.000 & 0.171 & 0.012 & & & \\
\hline & Wife & 0.400 & 0.071 & & & & \\
\hline & Both & 0.832 & 0.566 & & & & \\
\hline
\end{tabular}

$\overline{{ }^{a}}$ Nagelkerke R square which was 0.381 for the adjusted model; ${ }^{\mathrm{b}} \mathrm{CI}$ : Confidence Interval; ${ }^{\mathrm{c}} \mathrm{RC}$ : Reference Category; bolding indicates variables chosen for adjusted model i.e. those with significance level $<0.001$ and variable with highest $\mathrm{R}$ square in the case of potential collinearity. 
Table 3: Logistic regression of ever use of contraception $(n=440)$

\begin{tabular}{|c|c|c|c|c|c|c|c|}
\hline & & & Inadjuste & & & Adjustec & \\
\hline Variable & Categories & $\begin{array}{l}\text { Odds } \\
\text { ratio }\end{array}$ & $\begin{array}{c}\text { p- } \\
\text { value }\end{array}$ & $\begin{array}{c}\mathbf{R} \\
\text { square }^{\mathrm{a}}\end{array}$ & $\begin{array}{l}\text { Odds } \\
\text { ratio }\end{array}$ & $\begin{array}{c}95 \% \\
\mathbf{C I}^{\mathbf{b}}\end{array}$ & $\begin{array}{c}\text { p- } \\
\text { value }\end{array}$ \\
\hline Demographics & & & & & & & \\
\hline Sex & Female $\left(\mathrm{RC}^{\mathrm{c}}\right)$ & 1.000 & & 0.066 & 1.000 & & \\
\hline & Male & 2.795 & $<0.001$ & & 2.188 & $\begin{array}{l}1.121- \\
4.272\end{array}$ & 0.022 \\
\hline Age group & $\begin{array}{l}20-24 \text { years } \\
(\mathrm{RC})\end{array}$ & 1.000 & $<0.001$ & 0.156 & 1.000 & & 0.145 \\
\hline & $25-29$ years & 2.030 & 0.016 & & 0.733 & $\begin{array}{c}0.344- \\
1.564\end{array}$ & 0.422 \\
\hline & $30-34$ years & 2.367 & 0.004 & & 0.691 & $\begin{array}{c}0.279- \\
1.714\end{array}$ & 0.425 \\
\hline & $35-39$ years & 4.583 & $<0.001$ & & 0.377 & $\begin{array}{c}0.106- \\
1.342\end{array}$ & 0.132 \\
\hline & $40+$ years & 19.667 & $<0.001$ & & 1.744 & $\begin{array}{l}0.383- \\
7.941\end{array}$ & 0.472 \\
\hline $\begin{array}{l}\text { Husband's age } \\
\text { at marriage }^{\mathrm{d}}\end{array}$ & $\begin{array}{l}\text { Teenage years } \\
\text { (RC) }\end{array}$ & 1.000 & & 0.095 & & & \\
\hline & $20+$ years & 0.000 & 0.998 & & & & \\
\hline $\begin{array}{l}\text { Wife's age at } \\
\text { marriage }\end{array}$ & $\begin{array}{l}\text { Teenage years } \\
\text { (RC) }\end{array}$ & 1.000 & & 0.018 & & & \\
\hline & $20+$ years & 0.608 & 0.016 & & & & \\
\hline Age difference & $<5$ years $(\mathrm{RC})$ & 1.000 & & 0.013 & & & \\
\hline & $5+$ years & 1.501 & 0.044 & & & & \\
\hline Duration of & $<10$ years $(\mathrm{RC})$ & 1.000 & & 0.082 & 1.000 & & \\
\hline & $10+$ years & 2.907 & $<0.001$ & & 1.447 & $\begin{array}{c}0.684- \\
3.061\end{array}$ & 0.334 \\
\hline Family type & Nuclear (RC) & 1.000 & & 0.074 & 1.000 & & 0.593 \\
\hline & Joint & 0.358 & $<0.001$ & & 1.172 & $\begin{array}{l}0.655- \\
2.096\end{array}$ & \\
\hline $\begin{array}{l}\text { Desirable } \\
\text { family size }\end{array}$ & & 1.918 & $<0.001$ & 0.062 & & & \\
\hline Family size & & 1.826 & $<0.001$ & 0.094 & & & \\
\hline $\begin{array}{l}\text { Times of } \\
\text { pregnancy }\end{array}$ & & 2.036 & $<0.001$ & 0.136 & & & \\
\hline $\begin{array}{l}\text { Number of } \\
\text { living male } \\
\text { children }\end{array}$ & & 2.590 & $<0.001$ & 0.137 & & & \\
\hline $\begin{array}{l}\text { Number of } \\
\text { living female } \\
\text { children }\end{array}$ & & 1.281 & 0.040 & 0.014 & & & \\
\hline
\end{tabular}




\begin{tabular}{|c|c|c|c|c|c|c|c|}
\hline $\begin{array}{l}\text { Total number } \\
\text { of living } \\
\text { children } \\
\text { Socio- } \\
\text { economics }\end{array}$ & & 2.518 & $<0.001$ & 0.173 & 2.065 & $\begin{array}{l}1.373- \\
3.106\end{array}$ & $<0.001$ \\
\hline \multirow[t]{3}{*}{$\begin{array}{l}\text { Husband's } \\
\text { education }\end{array}$} & $\begin{array}{l}\text { Below } \\
\text { secondary (RC) }\end{array}$ & 1.000 & $<0.001$ & 0.100 & 1.000 & & $<0.001$ \\
\hline & Secondary & 0.100 & $<0.001$ & & 0.135 & $\begin{array}{c}0.042- \\
0.436\end{array}$ & 0.001 \\
\hline & $\begin{array}{l}\text { Above } \\
\text { secondary }\end{array}$ & 0.180 & 0.002 & & 0.289 & $\begin{array}{c}0.084- \\
0.991\end{array}$ & 0.048 \\
\hline \multirow[t]{3}{*}{$\begin{array}{l}\text { Wife's } \\
\text { education }\end{array}$} & $\begin{array}{l}\text { Below } \\
\text { secondary (RC) }\end{array}$ & 1.000 & 0.001 & 0.050 & & & \\
\hline & Secondary & 0.316 & $<0.001$ & & & & \\
\hline & $\begin{array}{l}\text { Above } \\
\text { secondary }\end{array}$ & 0.473 & 0.024 & & & & \\
\hline \multirow[t]{2}{*}{$\begin{array}{l}\text { Husband's } \\
\text { employment }\end{array}$} & $\begin{array}{l}\text { Unemployed/ } \\
\text { farming/other } \\
\text { (RC) }\end{array}$ & 1.000 & & 0.008 & & & \\
\hline & Service/business & 1.437 & 0.102 & & & & \\
\hline \multirow[t]{2}{*}{$\begin{array}{l}\text { Wife's } \\
\text { employment }\end{array}$} & $\begin{array}{l}\text { Housewife/ } \\
\text { farming/other } \\
\text { (RC) }\end{array}$ & 1.000 & & 0.034 & & & \\
\hline & Service/business & 2.120 & 0.001 & & & & \\
\hline \multirow{3}{*}{$\begin{array}{l}\text { Gender } \\
\text { View on sole } \\
\text { responsibility } \\
\text { woman in } \\
\text { nurturing and } \\
\text { caring of } \\
\text { children }\end{array}$} & & & & & & & \\
\hline & Yes (RC) & 1.000 & & 0.051 & 1.000 & & \\
\hline & No & 2.399 & $<0.001$ & & 2.760 & $\begin{array}{l}1.494- \\
5.101\end{array}$ & 0.001 \\
\hline \multirow{4}{*}{$\begin{array}{l}\text { Time provided } \\
\text { by husband for } \\
\text { nurturing and } \\
\text { caring of the } \\
\text { baby }\end{array}$} & $\begin{array}{l}\text { Adequate time } \\
\text { (RC) }\end{array}$ & 1.000 & $<0.001$ & 0.121 & 1.000 & & 0.019 \\
\hline & Some time & 1.977 & 0.016 & & 1.717 & $\begin{array}{l}0.880- \\
3.353\end{array}$ & 0.113 \\
\hline & Least time & 0.665 & 0.193 & & 0.596 & $\begin{array}{c}0.279- \\
1.276\end{array}$ & 0.183 \\
\hline & Not at all & 0.307 & $<0.001$ & & 0.546 & $\begin{array}{c}0.284- \\
1.049\end{array}$ & 0.069 \\
\hline $\begin{array}{l}\text { Possibility of } \\
\text { role reversal }\end{array}$ & Possible (RC) & 1.000 & 0.018 & 0.034 & & & \\
\hline
\end{tabular}




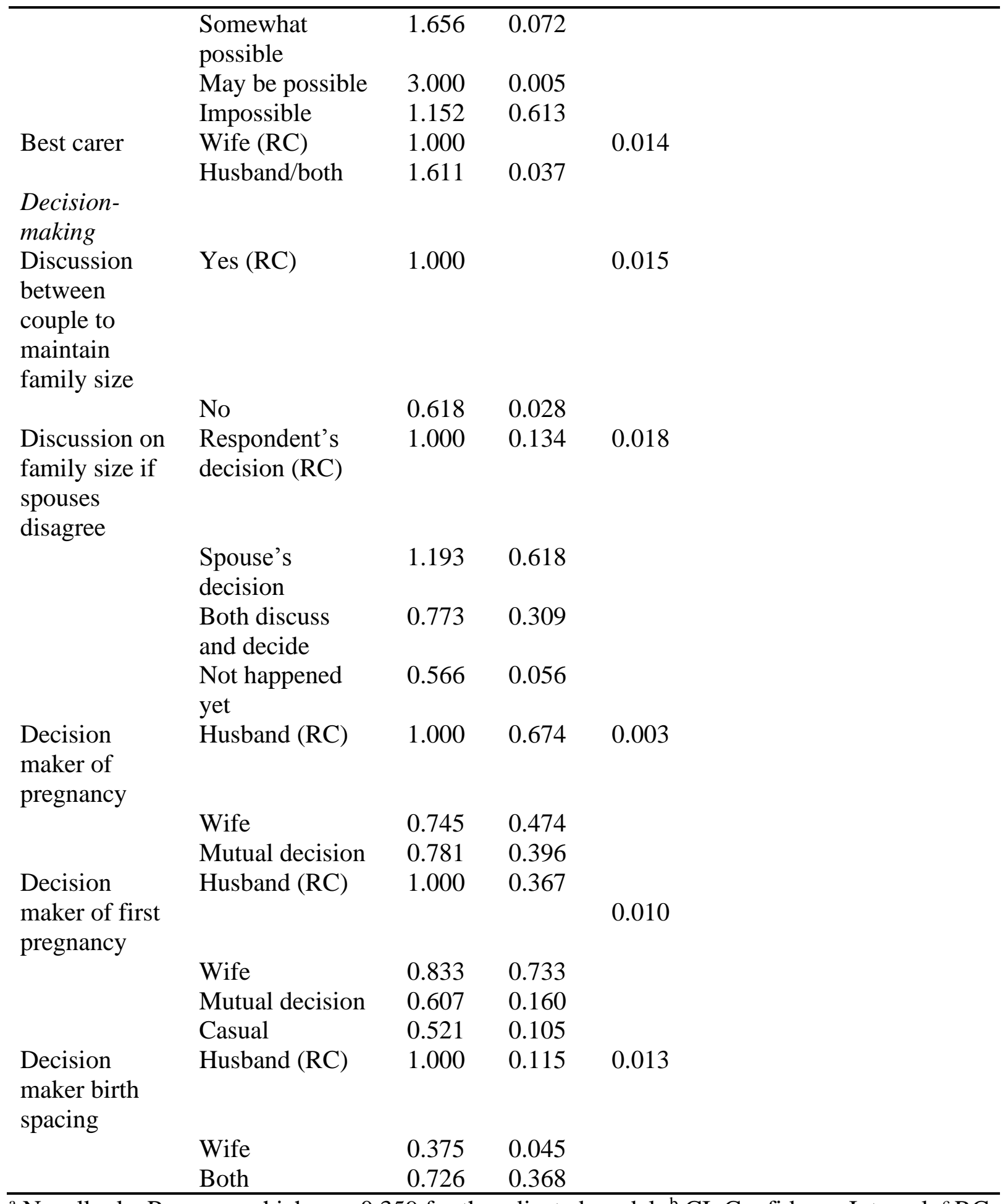

a Nagelkerke R square which was 0.359 for the adjusted model; ${ }^{\mathrm{b}}$ CI: Confidence Interval; ${ }^{\mathrm{c}} \mathrm{RC}$ : Reference Category; ${ }^{\mathrm{d}}$ Unacceptable large standard errors were experienced for husband's age at marriage, presumably because only 35/440 were married in their teens; bolding indicates variables chosen for the adjusted model i.e. those with significance level $<0.001$ and variable with highest $\mathrm{R}$ square in the case of potential collinearity. 